\title{
Whistleblowing in the healthcare sector: 'My name may be Tower Hospital, but my surname and my "isiduko" is the Eastern Cape Health Department'
}

On 23 August 2018, the Office of the Health Ombud released the 'Report on an investigation into allegations of patient mismanagement and patient rights violations at the Tower Psychiatric Hospital and Psychosocial Rehabilitation Centre' (TPHPRC). ${ }^{[1]}$ In this report, the whistleblower who had made a submission to the Ombud's Office on his concerns about possible human rights abuses at this facility was exceptionally harshly criticised, and essentially used as the 'fall person' on whom most of the public blame was placed. Not only was nothing less than the probable termination of his professional career recommended, but the whistleblower was also expected to make public apologies to the Minister of Health, the nation, the press ombud, the staff and patients (and their families) of Tower Hospital, and the Eastern Cape Department of Health $(\mathrm{ECDoH})$, as well as to his peers in psychiatry and the medical profession.

The report, however, has the following sentence appended: 'My name may be Tower Hospital, but my surname and my "isiduko" is the Eastern Cape Health Department', where an 'isiduko' refers to a Xhosa clan name:

'Isiduko (singular), iziduko (plural) in Xhosa are family names that are considered more important than surnames among Xhosa people. Much like the clan system of Scotland, each Xhosa person can trace their family history back to a specific male ancestor or stock. $^{\prime[2]}$

While much was said and reported on the whistleblowing clinician, by subtexting the report in this way, the health ombud seemed to also have strongly implied that actually a much more important underlying responsibility for the bigger context of the reported problems rested with the $\mathrm{ECDoH}$.

Another report in March 2018 on the conditions at TPHPRC, which was immediately embargoed by the health minister, was compiled by the ECDoH's Technical Task Team (ECDoH-TTT). Although this report was not available in the public domain, it was made available to the health ombud. Its content may not only have influenced the findings with regard to the whistleblower, but also other role players, such as the South African Society of Psychiatrists (SASOP). In addition to his recommendation on the whistleblower, the TPHPRC employees and the $\mathrm{ECDoH}$, the ombud also made several specific statements and recommendations about SASOP, including:

'It is suggested that SASOP focuses on its raison d'être, which as a professional body is to serve, guide and develop psychiatrists of the highest order, with high professional and ethical standards and who respect truth and are truthful. SASOP has no legal authority to conduct investigations and should resist such temptations to mislead public opinion and the media through the publication of false information on a poorly conducted "investigation" that it had no legal authority to undertake. In similar vein, the media should seek expert professionals or equivalent authorities before putting out "vital statistical information or data" to an unsuspecting public' (paragraph 5.1.6, page 60).
Following the release of the ombud's report, SASOP attempted to appeal these findings and recommendations. The notice of SASOP's appeal and accompanying documentation were, however, received by the Minister of Health's office later than the stipulated 30 days after the release of the report. Leave to appeal was declined by the minister on the basis of this late submission. The specific principles on which SASOP formulated their request to be allowed to appeal were: (i) SASOP's mandate and role as a professional association; (ii) potential conflicts of interest; (iii) methodology of the report; and (iv) whistleblower protection.

\section{SASOP's mandate and role as a professional association}

SASOP's constitutional rules include the following main objectives and 'core business' of the association: to monitor, evaluate and advise on policies related to the delivery of clinical services and the protection of patients' rights; to promote and uphold the principles of human rights, dignity and ethics in the practice of psychiatry; and to oppose unfair discrimination in the field of psychiatry. It was based on these reasons for its existence that the SASOP Board agreed to support the investigation of the alleged human rights abuses reported on by the whistleblower, who was - and still is - a SASOP and SASOP Eastern Cape Subgroup Committee member. The finding that SASOP 'misled the public through false information' was not substantiated.

\section{Potential conflicts of interest}

As its content was embargoed, the abovementioned ECDoH-TTT's report may include information on the potential conflict of interest that could have been experienced by one or more members of the task team. Such conflict may potentially have existed if, for example, a member was simultaneously operating in a direct service-delivery or academic supervisory/line function in relation to the whistleblower.

\section{Methodology of the report}

SASOP was also of the opinion that the methods applied in the investigation of the Tower Hospital matter were problematic. For example, while the investigation apparently made use of qualitative research methodology, the report does not incorporate a chain of evidence with quotations from the original source data. To improve trustworthiness of a qualitative investigation, triangulation is usually incorporated, but no clarity is provided on how such triangulation was actually achieved, as no evidence is provided that actual proof of the allegations made by participants was submitted or considered.

\section{Whistleblower protection}

SASOP cautioned at the time that the actions of the whistleblower in this case should have been considered in terms of the Protected 
Disclosures Act (PDA) No. 26 of 2000, as amended in the PDA Amendment Act No. 5 of 2017. ${ }^{[3]}$ The VOICE training manual[ ${ }^{[4]}$ of the Rural Health Advocacy Project notes that this PDA Amendment Act allows protection from victimisation arising from whistleblowing, if the disclosure pertains to: (i) crime; (ii) someone not complying with their legal duties; (iii) danger to health and safety; (iv) discrimination; or any of these, being concealed. ${ }^{[4]}$ The PDA provides four 'doors' through which to approach the whistleblowing:

'(i) disclosure to the employer; (ii) disclosure to a legal adviser;

(iii) disclosure to a regulatory body or independent body; and

(iv) through 'general protected disclosure' outside of the first three, if there is good cause that: (i) the impropriety is of an exceptionally serious nature; (ii) the disclosure has been made to the employer and no action has been taken within a reasonable period; (iii) the employee has reason to believe that the evidence will be concealed or destroyed if the disclosure is made to the employer and there is no prescribed regulatory body to approach; and (iv) the employee has reason to believe that he or she would be subject to occupational detriment. ${ }^{\prime[4]}$

As a result of the apparent bias towards the whistleblower in this case, the ombud's report on TPHPRC discouraged future whistleblowers. If protection of whistleblowers in terms of the existing legislation is not applied and achieved, the serious discouragement in the ombud's findings and reporting may extend to all healthcare delivery spheres. Healthcare workers will continue to feel profoundly threatened when attempting to report problematic behaviours and service-delivery challenges, even while it is actually expected of them in terms of their professional responsibility.

B Janse van Rensburg, MB ChB, FCPsych (SA), MMed, PhD Department of Psychiatry, Faculty of Health Sciences, University of the Witwatersrand, Johannesburg, South Africa; and past president, South African Society of Psychiatrists (2016 - 2018).

albert.jansevanrensburg@wits.ac.za

1. Makgoba MW, Office of the Health Ombud. Report on an investigation into allegations of patient mismanagement and patient rights violations at the Tower Psychiatric Hospital and Psychosocial Rehabilitation Centre. Pretoria: $\mathrm{OHO}, 23$ August 2018. http://ohsc.org.za/publications/ (accessed 23 August 2018).

2. Wikipedia. Isiduko. https://en.wikipedia.org/wiki/Xhosa clan names (accessed 24 August 2018)

3. South Africa. Protected Disclosures Amendment Act No. 5 of 2017. Governmen Gazette No. 41016. 2 Aug 2017. https://www.justice.gov.za/legislation/acts/2017005.pdf (accessed 26 November 2019)

4. Rural Health Advocacy Project. VOICE. A Health Care Provider's Guide to Reporting Healthcare Challenges: Principles, Tools and Strategies. Johannesburg: RHAP, 2017.

S Afr J Bioethics Law 2019;12(2):50-51. https://doi.org/10.7196/SAJBL.2019.v12i2.699 